\title{
Article
}

\section{Pilot Cultivation of the Local Endemic Cretan Marjoram Origanum microphyllum (Benth.) Vogel (Lamiaceae): Effect of Fertilizers on Growth and Herbal Quality Features}

\author{
Dimitrios Fanourakis ${ }^{1,+}{ }^{(D)}$, Konstantinos Paschalidis ${ }^{2,+}$, Georgios Tsaniklidis ${ }^{3}$ (D), Vasileios A. Tzanakakis ${ }^{2}$, \\ Fotis Bilias ${ }^{4}\left(\mathbb{D}\right.$, Eftihia Samara ${ }^{4} \mathbb{D}$, Eleftheria Liapaki ${ }^{2}$, Manal Jouini ${ }^{2}$, Ioannis Ipsilantis ${ }^{4} \mathbb{D}$, Eleni Maloupa ${ }^{5}$, \\ Georgios Tsoktouridis ${ }^{5,6}\left(\mathbb{D}\right.$, Theodora Matsi ${ }^{4, *}$ a and Nikos Krigas ${ }^{5, *(\mathbb{D}}$
}

check for updates

Citation: Fanourakis, D.; Paschalidis, K.; Tsaniklidis, G.; Tzanakakis, V.A.; Bilias, F.; Samara, E.; Liapaki, E.; Jouini, M.; Ipsilantis, I.; Maloupa, E.; et al. Pilot Cultivation of the Local Endemic Cretan Marjoram Origanum microphyllum (Benth.) Vogel (Lamiaceae): Effect of Fertilizers on Growth and Herbal Quality Features. Agronomy 2022, 12, 94. https:// doi.org/10.3390/agronomy12010094

Academic Editor: Cinzia

Margherita Bertea

Received: 7 December 2021

Accepted: 28 December 2021

Published: 30 December 2021

Publisher's Note: MDPI stays neutral with regard to jurisdictional claims in published maps and institutional affiliations.

Copyright: (C) 2021 by the authors. Licensee MDPI, Basel, Switzerland. This article is an open access article distributed under the terms and conditions of the Creative Commons Attribution (CC BY) license (https:// creativecommons.org/licenses/by/ $4.0 /)$
1 Laboratory of Quality and Safety of Agricultural Products, Landscape and Environment, Specialization of Floriculture and Landscape Architecture, Department of Agriculture, Hellenic Mediterranean University, Estavromenos, 71004 Heraklion, Greece; dfanourakis@hmu.gr

2 Department of Agriculture, School of Agricultural Sciences, Hellenic Mediterranean University, 71410 Heraklion, Greece; kpaschal@hmu.gr (K.P.); vtzanakakis@hmu.gr (V.A.T.); rialiapaki1@gmail.com (E.L.); maneljouini2@gmail.com (M.J.)

3 Institute of Olive Tree, Subtropical Crops and Viticulture, Hellenic Agricultural Organization Demeter, 73134 Chania, Greece; tsaniklidis@elgo.iosv.gr

4 Soil Science Laboratory, School of Agriculture, Aristotle University of Thessaloniki, 54124 Thessaloniki, Greece; fbilias@agro.auth.gr (F.B.); edsamara7@gmail.com (E.S.); iipsi@agro.auth.gr (I.I.)

5 Institute of Plant Breeding and Genetic Resources, Hellenic Agricultural Organization Demeter, P.O. Box 60458, Thermi, 57001 Thessaloniki, Greece; maloupa@bbgk.gr (E.M.); gtsok1@yahoo.co.uk (G.T.)

6 Theofrastos Fertilizers, Industrial Area of Korinthos, Irinis \& Filias, Ikismos Arion, Examilia, 20100 Korinthos, Greece

* Correspondence: thmatsi@agro.auth.gr (T.M.); nikoskrigas@gmail.com (N.K.)

$\dagger$ These authors contributed equally to this work.

\begin{abstract}
Wild phytogenetic resources are threatened by overexploitation. This pressure on species and natural ecosystems can be alleviated in part by recruiting and domesticating wild-growing species under pilot cultivation with tailor-made fertilization schemes. This study focused on the pilot cultivation of Origanum microphyllum - a critically endangered local endemic plant of Crete, Greece-investigating the effect of conventional and integrated nutrient management (INM) fertilizers by foliar or root application and biostimulant. Above-ground biomass together with leaf chlorophyll fluorescence and color (SPAD meter, DA meter, Chroma Meter) were determined. Leaf chlorophyll, antioxidant compound (carotenoids, phenols, flavonoids), and nutrient contents were also assessed. The results showed that fertilization did not significantly affect plant growth and leaf nutrient content. Root fertilization was associated with greener leaves compared to foliar. The same trend was generally evident for antioxidant compound content. The small size of leaves may have impeded the efficiency of the foliar application. In conclusion, root application of conventional or INM fertilizers seems more suitable to promote visual quality and herbal antioxidant profile of O. microphyllum, than the foliar one.
\end{abstract}

Keywords: antioxidant; biostimulant; carotenoids; flavonoids; Greece; herbal quality; medicinal plant; phenols; plant nutrition

\section{Introduction}

Conventional and complementary herbal medicines are traded globally both in developing and developed countries [1,2]. In the pharmaceutical industry, a considerable portion of target drugs still relies directly or indirectly on herbal material [2]. Herbal raw materials are also essential in other sectors (e.g., perfumery, cosmetics, and food industry) with a growing respective demand [3-5]. Although it is largely unnoticed by the public, a sizeable merit of the traded herbal material is yet derived from wild-growing plant populations of 
aromatic-medicinal plants (MAPs), threatening them at local scales and often across their ranges [6]. Many MAPs are nowadays threatened with extinction due to unsustainable practices, over-exploitation, and limited or compromised awareness [7]. In this perspective, considerable ecological risks arise not only for the range-restricted species, but also for the whole habitat in which these MAPs thrive in the wild [6]. Given the growing demand for herbal material in various economic sectors and the accelerating depletion of wild phytogenetic resources due to over-collection for direct use, the domestication of targeted species of interest and their pilot cultivation including the development of fertilization protocols appears to be a sustainable alternative.

Apart from developing new varieties of existing crops with superior characteristics in the face of climate change impacts, there is also a modern tendency in developing new crops to support livelihoods with a clear focus on the sustainable exploitation of neglected and underutilized species [8-12]. In agricultural crops, the nutrient requirements are conventionally satisfied by applying inorganic fertilizers. While stimulating plant growth and productivity when applied, their excessive use in several cases comes at the cost of a sizeable environmental impact [13]. For instance, the $\mathrm{N}$ and P surplus not recovered by the soil-plant system may drive eutrophication events in both freshwater systems and coastal zones $[13,14]$. In addition, the production of conventional fertilizers contributes to greenhouse gas emissions [15]. By contrast, organic fertilizers have been associated with low environmental footprint and decreased risks due to the slow release of plant nutrients to soil [15]. However, because of the latter the beneficial effect of organic fertilizers on crop productivity is sometimes deemed ambiguous. Therefore, replacing conventional with organic fertilizers is aimed to create a more eco-friendly and sustainable farming system. These environmental benefits can be further enhanced by the use of biostimulants [16]. Although biostimulants do not conventionally include nutrients and therefore cannot substitute fertilizers, they can decrease their utilization by stimulating increased root nutrient absorption [16]. Towards that direction, the combined use of conventional, organic fertilizers and biostimulants (the so-called integrated nutrient management; INM) represents a strategy that could sustain high yields and limit undesirable impact $[17,18]$.

It is known that diverse fertilization strategies may differentially affect not only plant growth and yield, but also product quality [15]. Herbal material quality encompasses several features, the relative importance of which differs based on the intended use $[4,5]$. A critical indicator of the herbal material quality is the content of antioxidant compounds determining high-added value $[14,19]$. These secondary metabolites act protectively towards the influence of several external stressors and limit many diseases in humans [20,21]. Among antioxidants, carotenoids, flavonoids, and phenolic compounds are of particular interest due to their strong potential to reduce stress events both at cellular and organismal levels $[14,19]$. There is already a lot of evidence that the herbal material produced with the use of organic and INM fertilizers has elevated the content of antioxidants as compared to conventional fertilizers [20,22-24]. In this respect, organic and INM fertilizers are an effective means of upgrading herbal material quality as related to health promoting compound content. There is also evidence that schemes with organic and INM fertilizers may stimulate leaf chlorophyll content, thus resulting to dark green color in leaf appearance which is often associated with high ornamental value [25]. The level and uniformity of leaf greenness is an additional quality indicator, which is conventionally employed from harvest to sale, involving growers, processors, distributors, and consumers [4].

This study deals with the development of a pilot and tailor-made cultivation and fertilization protocol for the Cretan marjoram Origanum microphyllum (Benth.) Vogel (Lamiaceae), aiming to optimize both yield and key herbal quality traits (color, antioxidant compound content). O. microphyllum is a local endemic plant of western and eastern Crete (Greece) [26]; this Cretan marjoram is well appreciated by local people, especially in the western part of the island where it is often directly harvested from the wild and traded at local markets in dried form particularly for its calming and anti-spasmodic properties and pleasant spicy scent [12]. Our study herein represents the first attempt to cultivate 
this Critically Endangered Cretan endemic plant [27] in its original native range (Crete), serving both conservation purposes and sustainable exploitation of this neglected and underutilized species. The latter is envisaged due to the multiple interest of the Cretan marjoram in three economic sectors, i.e., the ornamental [10], the agro-alimentary [11], and the medicinal-cosmetic sector [12].

\section{Materials and Methods}

\subsection{Origin of Plant Material}

In 2019, botanical expeditions were organized to explore different areas for wildgrowing populations of $O$. microphyllum with natural vigorous growth in rocky wild habitats of western and eastern Crete (Figure 1). The seed collections were performed using the authorized special permit of the Institute of Plant Breeding and Phytogenetic Resources, Hellenic Agricultural Organization Demeter (Permit 82336/879 of 18 May 2019 and 26895/1527 of 21 April 2021) which is annually issued by the Greek Ministry of Environment and Energy based on prior detailed reporting regarding the collections performed in the previous year. The seed collections were performed in the frame of the research project "Conservation and sustainable utilization of rare-threatened endemic plants of Crete for the development of new products with innovative precision fertilization" (acronym: PRECISE-M, T1EAK-05380).

The herbarium samples of O. microphyllum were taxonomically identified, and a unique IPEN (International Plant Exchange Network) accession number was assigned to them by the Institute of Plant Breeding and Genetic Resources (IPBGR) of the Hellenic Agricultural Organization Demeter (ELGO Demeter). New plants were initially raised ex-situ through seed germination trials (pretreatment by seed immersing in 50 ppm GA3 solution for $24 \mathrm{~h}$ ) and pilot rooting of cuttings of the IPEN accession number GR-1-BBGK-19,31 assigned to the original plant collection from Mt. Dikti, eastern Crete at altitude of $1000 \mathrm{~m}$. These pilot propagation trials resulted in adequate number of ex situ raised plants for further field experimentation which were transplanted in $2 \mathrm{~L}$ plastic pots from the company of AFI GLAVAKI KE SIA OE, Tree and Plant Nurseries, Aridea PELLAS, GR-58400, Greece.

\subsection{Establishment of Field Experiment}

The field experiment was located in a research field of $20 \times 25 \mathrm{~m}\left(35^{\circ} 19^{\prime} \mathrm{N}, 25^{\circ} 6^{\prime} \mathrm{E}\right.$, altitude $60 \mathrm{~m}$ above sea level) of the Hellenic Mediterranean University, Heraklion, Crete (Greece). On 21 January 2021, potted plants of O. microphyllum were established in field at $80 \mathrm{~cm}$ distance between rows and at $40 \mathrm{~cm}$ between plant individuals. The length of each row was $20 \mathrm{~m}$ with east-west direction. The experiment also included as "guard plants" other local Cretan endemics, i.e., Carlina diae (Rech. f.) Meusel and Kästner, Sideritis syriaca L. subsp. syriaca, Origanum dictamnus L., and Verbascum arcturus L.) established in equal numbers as the species under study, thus reducing heterogeneity in air velocity between inner and outer rows.

The experimental design involved completely randomized blocks (three blocks per treatment; see below) and 10 O. microphyllum plants per block, which were randomly planted in different rows. Six fertilization treatments were introduced starting from 11 March 2021 and they were weekly performed till the final harvest. Irrigation was supplied through an automatic system using $2 \mathrm{~L} \mathrm{~h}^{-1}$ adjustable drippers, supplying the plants with water three times per week. No visible pests and diseases were necessary to control, but the elimination of weeds was frequently required and it was manually achieved. The final harvest of O. microphyllum was completed at the end of June 2021. 


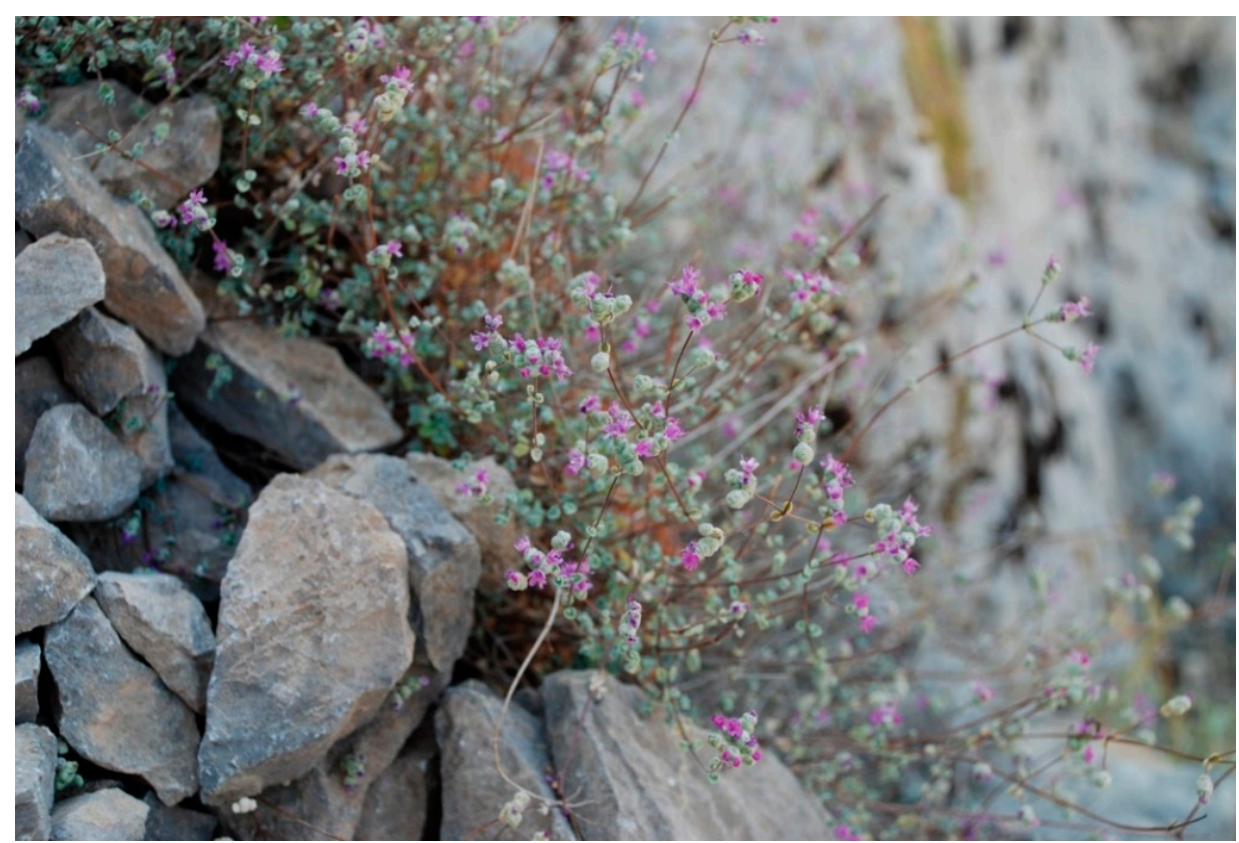

(a)

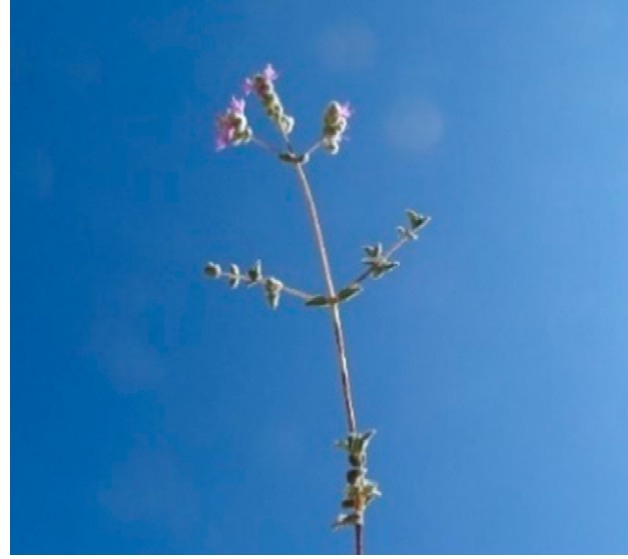

(b)

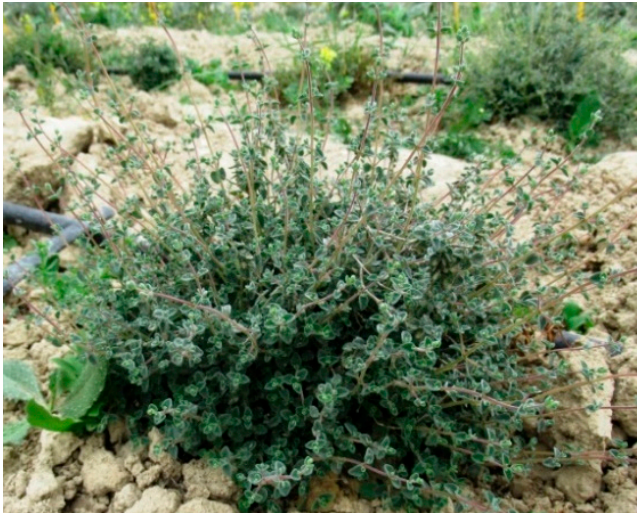

(d)

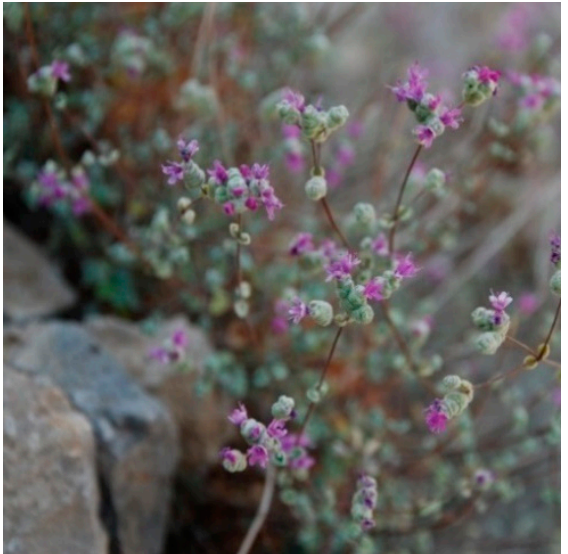

(c)

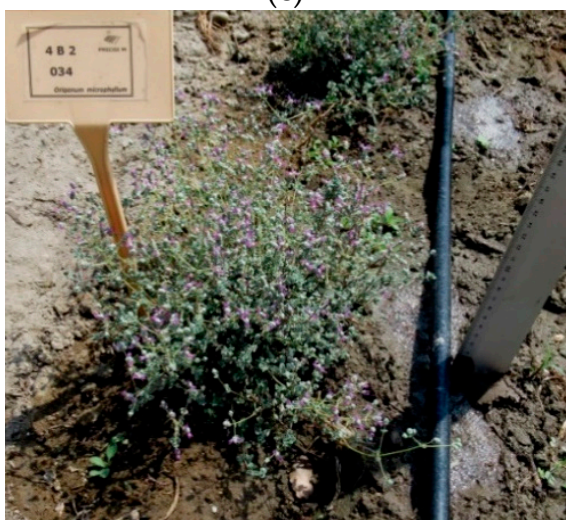

(e)

Figure 1. The Critically Endangered local endemic of Crete Origanum microphyllum (Cretan marjoram): (a) in its wild rocky habitat in Samaria gorge, Crete; (b) with flowering shoots bearing small leaves; (c) with densely hairy verticillasters with violet corollas; (d,e) at vegetative and early flowering stage in its pilot cultivation area (campus of the Hellenic Mediterranean University in Heraklion, Crete). 


\subsection{Soil Analysis}

A composite surface soil sample, constituted of 10 sub-samples, was obtained from the research field; it was fined using a $2 \mathrm{~mm}$ sieve and was analyzed in triplicate for the properties described hereafter. Particle size distribution was determined by the hydrometer method [28]. Organic $C$ was determined by the wet oxidation method [29]. The Kjeldahl method was used to estimate the total $\mathrm{N}$ content [30] and $\mathrm{CaCO}_{3}$ was measured with a calcimeter. The $\mathrm{pH}$ was determined in a 1:2 $(w / v)$ water suspension, the electrical conductivity was estimated in the saturation extract $\left(\mathrm{EC}_{\mathrm{se}}\right)$ and the sodium absorption ratio (SAR) was evaluated by the concentrations of water-soluble $\mathrm{Na}, \mathrm{Ca}$, and $\mathrm{Mg}$ [31], and the cation exchange capacity (CEC) was calculated by the $\left[\mathrm{Co}\left(\mathrm{NH}_{3}\right)_{6}\right] \mathrm{Cl}_{3}$ method (ISO 23470).

Phosphorus was extracted using $0.5 \mathrm{M} \mathrm{NaHCO}_{3}, \mathrm{pH} 8.5$ and was measured by the molybdenum blue-ascorbic acid method [32]. Both $\mathrm{NO}_{3}$ and $\mathrm{NH}_{4}$ ions available in soil were extracted with $1 \mathrm{M} \mathrm{KCl}$ and they were measured using UV-Vis spectrometry and the sodium salicylate-sodium nitroprusside method, respectively [33]. Exchangeable $\mathrm{K}, \mathrm{Ca}$, and $\mathrm{Mg}$ were extracted with $1 \mathrm{M} \mathrm{CH}_{3} \mathrm{COONH}_{4}, \mathrm{pH} 7$ [34]; $\mathrm{K}$ was estimated with flame photometry, while $\mathrm{Ca}$ and $\mathrm{Mg}$ using atomic absorption spectrometry. The micronutrients $\mathrm{Cu}, \mathrm{Zn}, \mathrm{Fe}$, and $\mathrm{Mn}$ available in soil were extracted with DTPA [35] and were measured using atomic absorption spectrometry as well. Soil available B was extracted with hot water and was estimated with the azomethine-H method using UV-Vis spectrometry [36].

\subsection{Fertilization Treatments}

During the experimentation with O. microphyllum fertilization, treatments were monitored weekly using INM and conventional fertilizers in liquid or soluble granule form or water (control) administered by soil and foliar applications. The foliar treatments were performed using a $5 \mathrm{~L}$ plastic handheld sprayer (working in low pressure) until apparent wetness, and the soil applications were manually performed $(100 \mathrm{~mL}$ nutrient solution per plant). The INM involved four commercial semi-organic fertilizers from THEOFRASTOS company (Industrial area of Korinthos, GR-20100 Korinthos, Greece), which were made from high quality edible raw materials and limited amounts of chemical solvents. The conventional fertilizers were supplied in soluble powder or granule form, except the liquid fertilizer for micronutrients (Plex Mix). The composition and commercial details of fertilizers are demonstrated in Table S1 (Supplementary Material).

The pilot fertilization treatments of $O$. microphyllum involved:

A. INM by foliar application (INM-fa): the nutrient solution composed of THEORUN at $7 \mathrm{~mL} \mathrm{~L}^{-1}$, THEOCAL at $1.5 \mathrm{~g} \mathrm{~L}^{-1}$, THEOFAST at $5 \mathrm{~mL} \mathrm{~L}^{-1}, 10-47-10$ at $3.2 \mathrm{~g} \mathrm{~L}^{-1}$, 0-0-52 at $2.07 \mathrm{~g} \mathrm{~L}^{-1}$, micronutrients Plex Mix at $1.5 \mathrm{~mL} \mathrm{~L}^{-1}$, and $\mathrm{MgSO}_{4}$ at $0.6 \mathrm{~g} \mathrm{~L}^{-1}$.

B. Conventional fertilization by foliar application (ChF-fa): the nutrient solution composed of 34.4-0-0 at $2.7 \mathrm{~g} \mathrm{~L}^{-1}, \mathrm{Ca}\left(\mathrm{NO}_{3}\right)_{2}$ at $1.7 \mathrm{~g} \mathrm{~L}^{-1}, 10-47-10$ at $3.2 \mathrm{~g} \mathrm{~L}^{-1}, 0-0-52$ at $2.27 \mathrm{~g} \mathrm{~L}^{-1}$, micronutrients Plex Mix at $1.5 \mathrm{~mL} \mathrm{~L}^{-1}$, and $\mathrm{MgSO}_{4}$ at $0.6 \mathrm{~g} \mathrm{~L}^{-1}$.

C. Control: foliar and soil applications of tap water (C).

D. INM by soil application (INM-sa): the nutrient solution composed of THEORUN at $7 \mathrm{~mL} \mathrm{~L}^{-1}, 0-0-52$ at $2.1 \mathrm{~g} \mathrm{~L}^{-1}$, THEOCAL at $1.5 \mathrm{~g} \mathrm{~L}^{-1}, 10-47-10$ at $3.2 \mathrm{~g} \mathrm{~L}^{-1}$, THEOMASS at $10 \mathrm{~mL} \mathrm{~L}^{-1}$, micronutrients Plex Mix at $1.5 \mathrm{~mL} \mathrm{~L}^{-1}$, and $\mathrm{MgSO}_{4}$ at $0.3 \mathrm{~g} \mathrm{~L}^{-1}$.

E. Conventional fertilization by soil application (ChF-sa): the nutrient solution was composed of 10-47-10 at 3.2 $\mathrm{g} \mathrm{L}^{-1}, 34,4-0-0$ at $2.7 \mathrm{~g} \mathrm{~L}^{-1}, 0-0-52$ at $2.3 \mathrm{~g} \mathrm{~L}^{-1}, \mathrm{Ca}\left(\mathrm{NO}_{3}\right)_{2}$ at $1.7 \mathrm{~g} \mathrm{~L}^{-1}$, micronutrients Plex Mix at $1.5 \mathrm{~mL} \mathrm{~L}^{-1}$, and $\mathrm{MgSO}_{4}$ at $0.3 \mathrm{~g} \mathrm{~L}^{-1}$.

F. A mixture of plant extracts used as biostimulant by soil application (MPE-sa): the nutrient solution was composed of THEOMASS at $10 \mathrm{~mL} \mathrm{~L}^{-1}$.

\subsection{Plant Measurements}

Periodical plant and leaf level measurements were conducted until the end of flowering of O. microphyllum at the experimental setting (25 May 2021). The selected leaf samples for 
measurements were fully expanded with no apparent symptoms of either insect damage or pathogen infection. In all cases, $15 \mathrm{~min}$ was the maximum time between sampling and the initiation of the evaluation; otherwise, leaf samples were placed in vials, flash-frozen in liquid nitrogen, and were transferred for storage in a freezer $\left(-80^{\circ} \mathrm{C}\right)$. Replicate leaves were sampled from separate plant individuals.

\subsubsection{Non-Invasive Evaluation of Leaf Coloration at Three Growth Stages}

Since leaf coloration is known to be affected by fertilization with implications for both visually perceived quality and photosynthetic capacity [37], three different methods were employed in the current study to evaluate leaf coloration: (i) leaf SPAD value estimating chlorophyll content with the use of a SPAD-502 meter (Konica Minolta Corp., Solna, Sweden); (ii) the index of absorbance difference $\left(\mathrm{I}_{\mathrm{AD}}\right)$ was estimated in leaves by using the DA meter (tr DA Meter, T.R. Turoni, Italy); (iii) leaf color was calculated by using a Chroma Meter (Model CR-400, Minolta Corp., Japan). CIE L*a*b* parameters were recorded using D65 illuminants and a $10^{\circ}$ Standard Observer as a reference system. $L^{*}$ was used to specify lightness ranging from 0 (black) to 100 (white); $a^{*}$ was used to define the intensity in a range of green to red (negative values indicate green and positive values red); $b^{*}$ was used to define the intensity in a range from blue to yellow (negative values specify blue and positive values yellow [5]). All these measurements were performed in situ during three different growth stages of $O$. microphyllum (vegetative, early flowering, and full flowering). Three points were recorded per replicate leaf, which were further averaged, and three replicate leaves were assessed per treatment.

\subsubsection{Non-Invasive Evaluation of Photosynthetic Performance at Three Growth Stages}

The leaf photosynthetic performance was estimated by calculating the ratio of variable to maximum chlorophyll fluorescence $\left(\mathrm{F}_{v} / \mathrm{F}_{m}\right)[38,39]$, using a chlorophyll fluorometer (OS-30P, Op-tiSciences, Hudson, NH, USA). Leaves were first dark-adapted ( $\geq 20 \mathrm{~min}$ ) by employing leaf clips and then the $\mathrm{F}_{v} / \mathrm{F}_{m}$ was estimated by applying a saturated photosynthetic photon flux density of $3000 \mu \mathrm{mol} \mathrm{m} \mathrm{m}^{-2} \mathrm{~s}^{-1}$. These measurements were performed in situ at three different developmental stages of $O$. microphyllum (vegetative, early flowering, and full flowering). Similarly, three points were recorded per replicate leaf and further averaged, and three replicate leaves were assessed per treatment.

\subsubsection{Plant Growth}

The growth of $O$. microphyllum plant individuals was evaluated using the aboveground part of the plants (fresh and dry weight) ( $\pm 0.01 \mathrm{~g}$; MXX-412; Denver Instruments, Bohemia, NY, USA). The samples were placed in a forced-air drying oven for $72 \mathrm{~h}$ at $80{ }^{\circ} \mathrm{C}$ following the measurements of the fresh weight of the plants, with six replicate plants per treatment.

\subsubsection{Leaf Photosynthetic Pigment Content}

A total of $0.5 \mathrm{~g}$ for each sample was fine chopped and homogenized with the addition of $10 \mathrm{~mL}$ of $80 \%$ acetone and was then filtered. The filtered extract was diluted by adding $2 \mathrm{~mL}$ of $80 \%$ acetone per $\mathrm{mL}$ of extract. The whole process of extraction took place in a dark room since chlorophyll is light sensitive [40,41]. The final extract was subjected to reading on a spectrophotometer (Mapada UV-1800; Shanghai. Mapada Instruments Co., Ltd., Shanghai, China) and the total chlorophyll and carotenoid contents were estimated [42]. Three leaves were assessed per treatment, four samples were pooled for each replicate (collected from different plant individuals), and the assay was performed twice.

\subsubsection{Leaf Total Phenolic and Total Flavonoid Contents}

Leaf samples at $0.1 \mathrm{~g}$ were extracted with $1 \mathrm{~mL}$ of $80 \%$ aqueous methanol in an ultrasonic bath for $10 \mathrm{~min}$ and then were centrifuged at $15,000 \times \mathrm{g}$ for $10 \mathrm{~min}$. Following the protocol of Chen et al. (2021) [19], the content of total phenols and total flavonoids 
was calculated using the Folin-Ciocalteu assay and aluminum chloride colorimetric assay, respectively. The absorbance against prepared reagent blank was referenced using a microplate reader (Infinite 200 PRO, TECAN, Männedorf, Switzerland). The total phenolic content was measured using gallic acid as the standard reference and the gallic acid equivalent (GAE) was expressed as $\mathrm{mg}$ per $\mathrm{g}$ fresh mass. The total flavonoid content was measured using rutin as the standard reference and the rutin equivalent (RUE) was expressed as mg per $\mathrm{g}$ fresh mass. Three leaves were assessed per treatment, four samples were pooled for each replicate (collected from different plant individuals) and the assay was performed twice.

\subsubsection{Leaf Soluble Sugar Content}

Leaf samples at $0.1 \mathrm{~g}$ were fine chopped and homogenized in $1 \mathrm{~mL}$ deionized water and incubated in a water bath at $100{ }^{\circ} \mathrm{C}$ for $30 \mathrm{~min}$, following centrifugation at $15,000 \times g$ for $15 \mathrm{~min}$ at room temperature $\left(25^{\circ} \mathrm{C}\right)$. Then, $0.1 \mathrm{~mL}$ of the previous solution was mixed with anthrone ethyl acetate and $\mathrm{H}_{2} \mathrm{SO}_{4}$ and the soluble sugar content was assayed in the supernatant by measuring the absorbance at $630 \mathrm{~nm}$ using a spectrophotometer (Mapada UV-1800; Shanghai. Mapada Instruments Co., Ltd., Shanghai, China), according to Dubois et al. (1956) [43]. Soluble sugar content was expressed per fresh weight basis $\left(\mathrm{mg} \mathrm{g}^{-1}\right)$. Three leaves were assessed per treatment, four samples were pooled for each replicate (collected from different plant individuals), and the assay was performed twice.

\subsubsection{Leaf Nutrient Analyses}

Leaf nutrient analysis was conducted in order to assess the role of fertilization on plant nutrition. The samples of O. microphyllum were washed with distilled water and then dried at $70{ }^{\circ} \mathrm{C}$, weighed, ground, and analyzed for total $\mathrm{N}$ by the Kjeldahl method [30]. In addition, sub-samples were ashed at $500{ }^{\circ} \mathrm{C}$ for $4 \mathrm{~h}$ minimum [44] and then the ash was dissolved in $2 \mathrm{M} \mathrm{HCl}$, following filtration. The filtrate was used to determine the $\mathrm{P}, \mathrm{K}, \mathrm{Ca}, \mathrm{Mg}, \mathrm{Cu}, \mathrm{Zn}, \mathrm{Fe}, \mathrm{Mn}$, and $\mathrm{B}$ content in the samples by employing the analytical methods described previously for soil analysis and the nutrient content was expressed per dry weight basis. Three replicates were assessed per treatment, four samples were pooled for each replicate (collected from different plant individuals), and the assay was performed twice.

\subsection{Statistical Analysis}

The data of each property were tested for homogeneity of variances (Duncan's test) and analysis of variance (ANOVA) was conducted. Then, the protected least significant differences test (LSD-test) was used for means comparison, at $p \leq 0.05$ For all statistical analyses, the SAS software was used (SAS Institute, Cary, NC, USA).

\section{Results}

\subsection{Soil Properties of the Pilot Field}

The soil of the pilot field had sandy-loam texture and alkaline reaction. In addition, it was calcareous with high content of $\mathrm{CaCO}_{3}$ and low organic $\mathrm{C}$ content, $\mathrm{EC}_{\text {se, }}$ and SAR. Moreover, the soil had high content of available $\mathrm{NO}_{3}-\mathrm{N}$ [45] and sufficient concentrations of available $\mathrm{P}$ and $\mathrm{K}[46,47]$. As for the soil available B and metallic micronutrients, they ranged at levels higher or similar to the sufficiency levels reported [48] (Supplementary Table S2).

\subsection{Leaf Color}

The effect of fertilization on leaf color (a critical herb quality trait) was evaluated at three growth stages (vegetative, early flowering, full flowering) by employing three techniques (SPAD meter, DA meter, Chroma Meter). At vegetative and early flowering stages, leaf SPAD value differences among treatments were not significant (Figure 2A,B). At full flowering stage, plants treated with INM-sa had higher leaf SPAD value as compared to 
the ones receiving foliar fertilization (i.e., INM-fa and ChF-fa; Figure 2C). However, despite the differences observed among certain fertilization treatments, in all cases the SPAD values were similar to that of control.
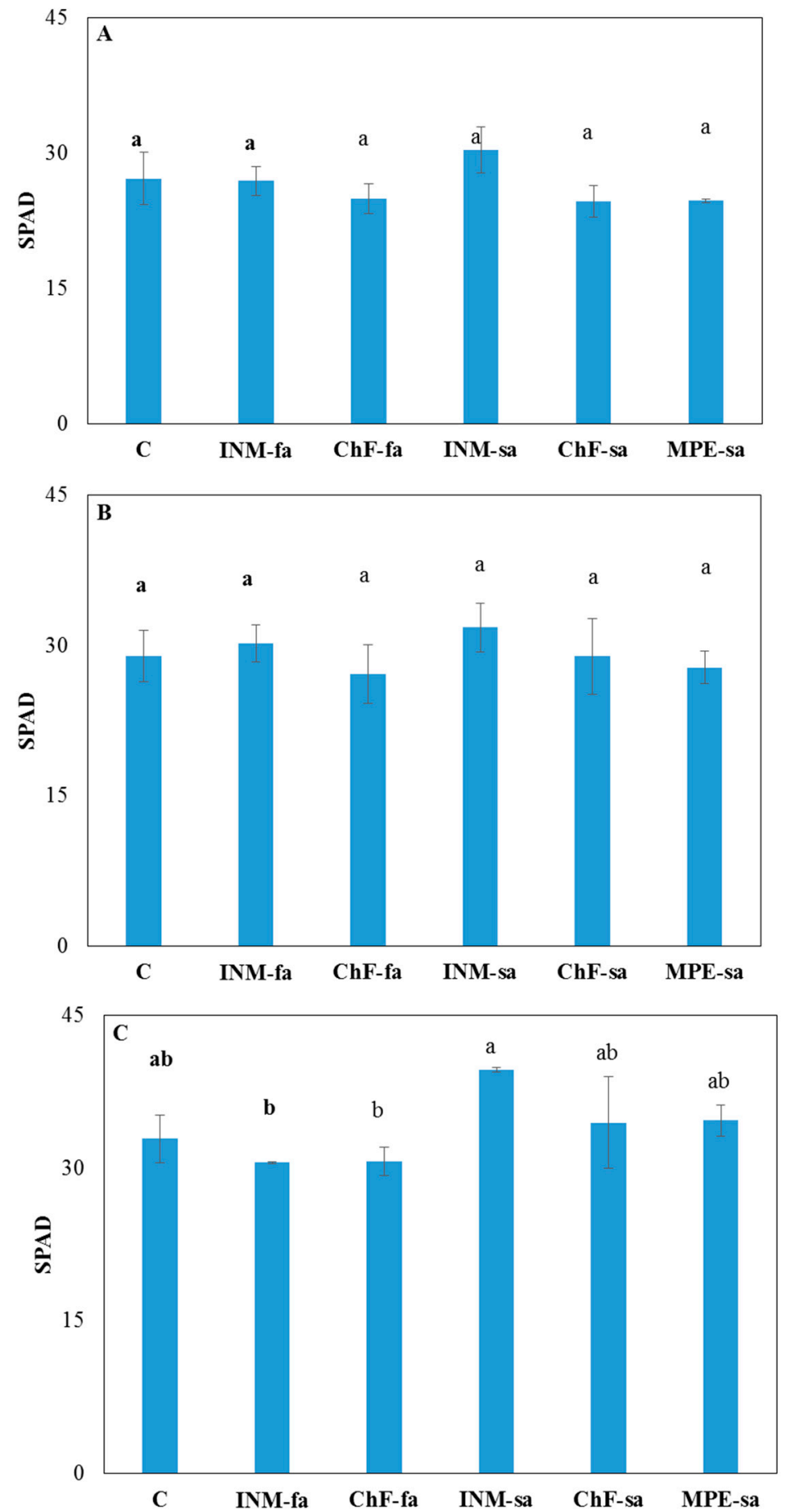

Figure 2. Effect of fertilization through different (root/foliar) application methods on leaf SPAD value of Origanum microphyllum at: (A) vegetative; (B) early flowering; (C) full flowering stage. C: control (water); INM: integrated nutrient management (INM) by foliar (INM-fa) or soil application (INM-sa); ChF: conventional fertilization by foliar (ChF-fa) or soil application (ChF-sa); MPE-sa: mixture of plant extracts as biostimulant by soil application. Values represent the mean of three replicates \pm SEM. Within each plot different letters indicate significant differences. 
At vegetative stage, leaf $\mathrm{I}_{\mathrm{AD}}$ (index of absorbance difference) of plants receiving ChF-sa was higher compared to control plants, and those receiving INM-sa and MPE-sa (Supplementary Figure S1A). At early flowering stage, differences among all treatments were not significant (Supplementary Figure S1B), whereas at full flowering stage, plants receiving foliar fertilization (i.e., INM-fa and ChF-fa) had higher leaf $\mathrm{I}_{\mathrm{AD}}$ compared to plants receiving fertilization through the root (i.e., INM-sa, ChF-sa, and MPE-sa). Once more, at the particular growth stage, in all cases of fertilization treatments the leaf $\mathrm{I}_{\mathrm{AD}}$ was similar to that of control (Supplementary Figure S1C).

At all three growth stages, the leaf $\mathrm{L}^{*}$ value (expressing lightness) of plants receiving ChF-sa or MPE-sa was lower in comparison to the rest of the treatments (Supplementary Figure S2).

At all three growth stages, the leaf $\mathrm{a}^{*}$ value (expressing intensity in the green to red range) was higher in plants receiving foliar fertilization (i.e., INM-fa and ChF-fa) compared to control plants or those receiving ChF-sa and MPE-sa (Supplementary Figure S3).

At all three growth stages, the leaf $\mathrm{b}^{*}$ value (expressing intensity in the blue to yellow range) was lower in plants receiving foliar fertilization (i.e., INM-fa and ChF-fa) and INM-sa compared to the rest of the treatments (Supplementary Figure S4).

\subsection{Leaf Photosynthetic Performance}

At three growth stages, the effect of fertilization on the overall photosynthetic efficiency was evaluated by determining $\mathrm{F}_{v} / \mathrm{F}_{m}$ values (Figure 3). At vegetative stage, all fertilization treatments had $\mathrm{F}_{v} / \mathrm{F}_{m}$ values similar to control (Figure $3 \mathrm{~A}$ ). At early flowering stage, the leaves of plants receiving MPE-sa had the highest $\mathrm{F}_{v} / \mathrm{F}_{m}$ value compared to the rest of the treatments, including the control (Figure $3 \mathrm{~B}$ ). At full flowering stage, plants receiving ChF-sa and MPE-sa had the highest $\mathrm{F}_{v} / \mathrm{F}_{m}$ values, while the ones receiving INM-fa had the lowest (Figure 3C).

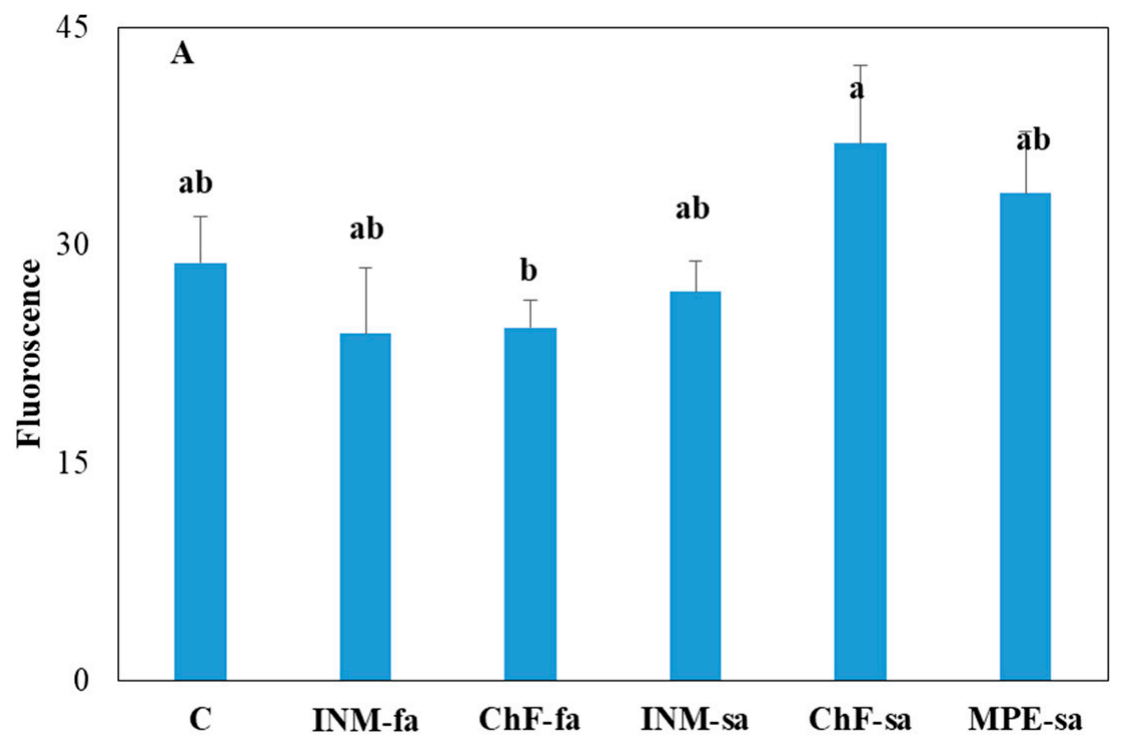

Figure 3. Cont. 

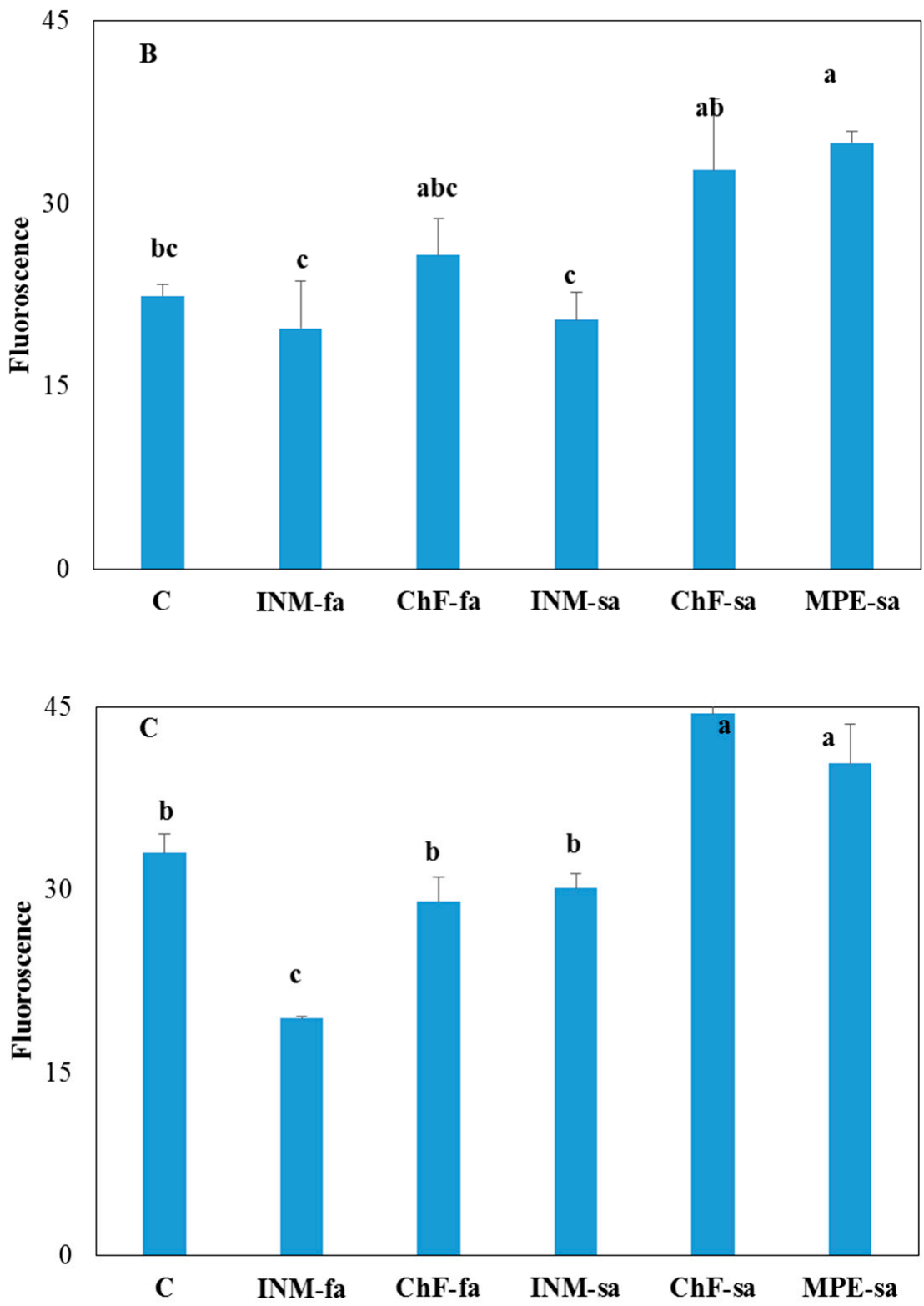

Figure 3. Effect of fertilization through different (root/foliar) application methods on chlorophyll fluorescence value of Origanum microphyllum at: (A) vegetative; (B) early flowering; (C) full flowering stage. C: control (water); INM: integrated nutrient management (INM) by foliar (INM-fa) or soil application (INM-sa); ChF: conventional fertilization by foliar (ChF-fa) or soil application (ChF-sa); MPE-sa: mixture of plant extracts as biostimulant by soil application. Values represent the mean of three replicates \pm SEM. Within each plot different letters indicate significant differences.

\subsection{Leaf Chlorophyll Content and Antioxidant Compound Content}

Plants receiving ChF-sa showed the highest leaf chlorophyll content, followed by the ones receiving IMN-sa (Figure 4A). The lowest leaf chlorophyll content was noted in plants receiving INM-fa (Figure 4A). 

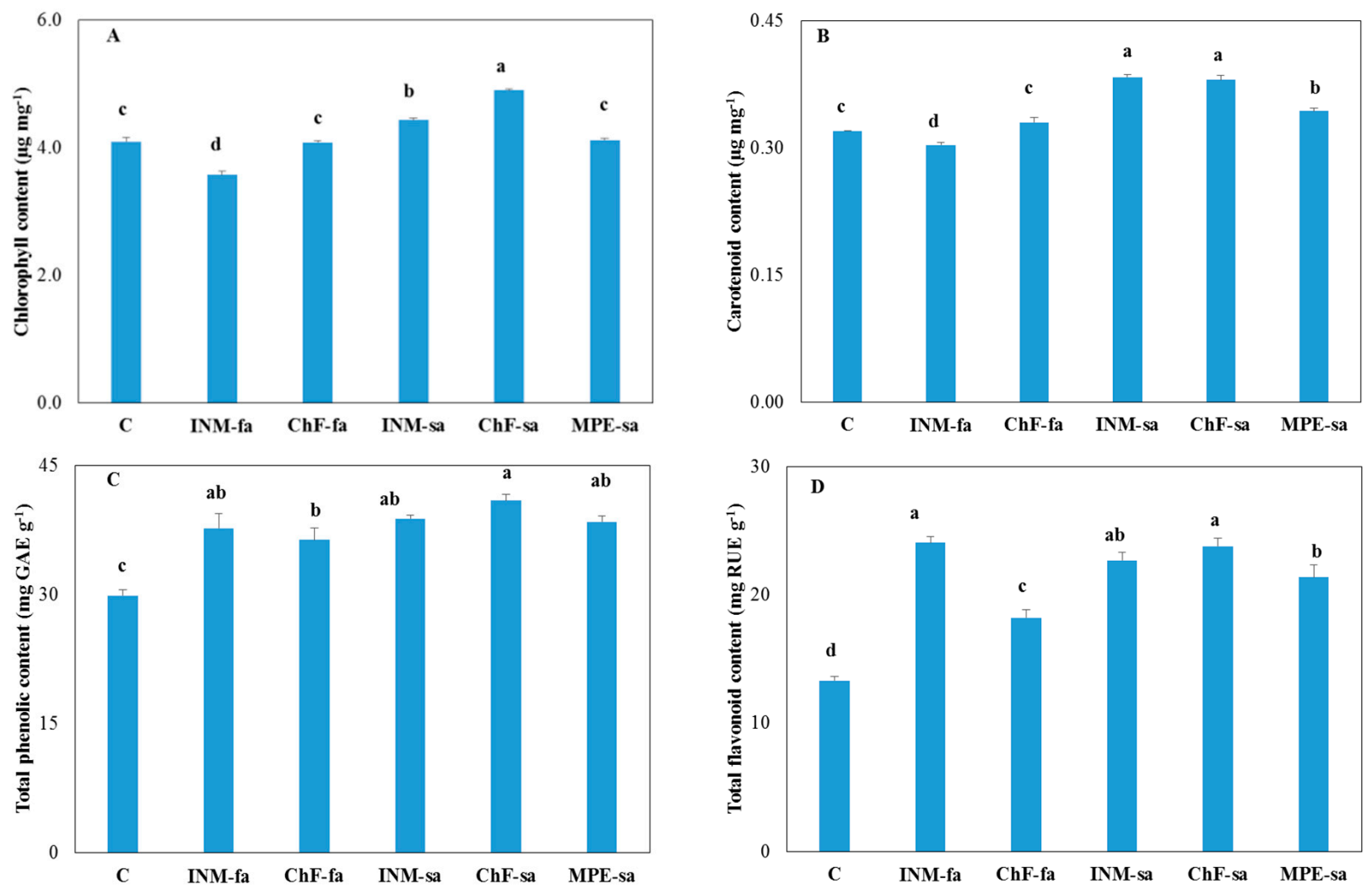

Figure 4. Effect of fertilization through different (root/foliar) application methods on: (A) leaf chlorophyll; (B) carotenoid; (C) total phenol; (D) total flavonoid content of Origanum microphyllum. C: control (water); INM: integrated nutrient management (INM) by foliar (INM-fa) or soil application (INM-sa); ChF: conventional fertilization by foliar (ChF-fa) or soil application (ChF-sa); MPE-sa: mixture of plant extracts as biostimulant by soil application. Values represent the mean of three replicates \pm SEM. Within each plot different letters indicate significant differences.

The fertilization affected the content of leaves in important antioxidants (carotenoids, phenols, and flavonoids). Plants receiving ChF-sa and INM-sa had the highest leaf carotenoid content, followed by the ones receiving MPE-sa (Figure 4B). Plants receiving INM-fa had the lowest leaf carotenoid content (Figure 4B).

Independently of the applied scheme, plants receiving fertilization showed higher leaf phenolic content compared to control plants (Figure 4C), while those receiving ChF-sa also presented higher leaf phenolic content in comparison to ChF-fa (Figure 4C).

Regardless of the fertilization scheme, plants receiving fertilization had higher leaf flavonoid content compared to control (Figure 4D), and those receiving ChF-fa showed lower leaf flavonoid content compared to the other fertilization schemes (Figure 4D).

\subsection{Leaf Soluble Sugar Content}

Independently of the applied scheme, plants receiving fertilization presented higher leaf soluble sugar content compared to control and those receiving ChF-sa had lower leaf soluble sugar content compared to the ones receiving ChF-fa, INM-fa, and INM-sa (Figure 5). 


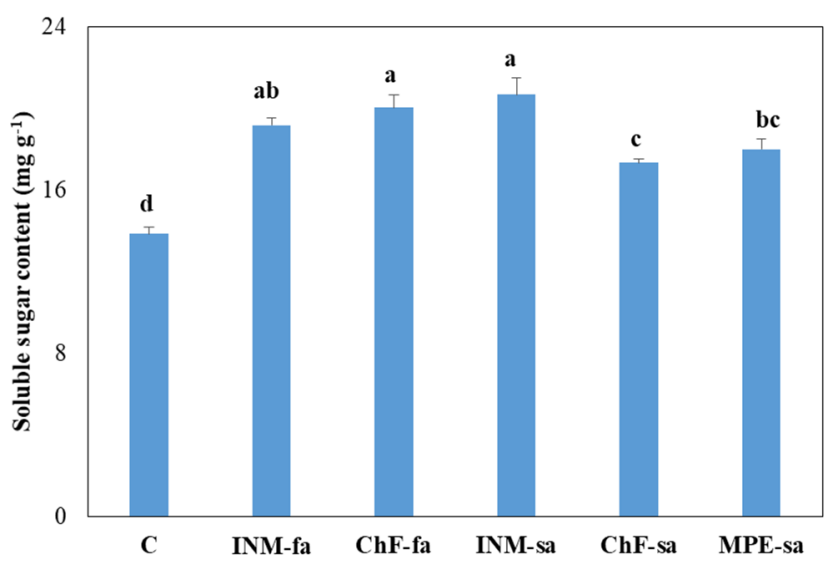

Figure 5. Effect of fertilization through different (root/foliar) application methods on leaf soluble sugar content of Origanum microphyllum. C: control (water); INM: integrated nutrient management (INM) by foliar (INM-fa) or soil application (INM-sa); ChF: conventional fertilization by foliar (ChF-fa) or soil application (ChF-sa); MPE-sa: mixture of plant extracts as biostimulant by soil application. Soluble protein content was expressed per fresh weight basis. Values represent the mean of three replicates \pm SEM. Within each plot different letters indicate significant differences.

\subsection{Plant Growth and Leaf Nutrients Content}

Fertilization was not found to affect either the above-ground fresh and dry plant mass or the water content (data not shown).

The effect of fertilization scheme on nutrient absorption by plants was performed by analyzing leaves for plant essential macronutrients and micronutrients (Tables 1 and 2, respectively). As far as the macronutrients are concerned, $\mathrm{Mg}$ concentration was not affected by fertilization. For the rest macronutrients, significant differences among all treatments were observed; however, except for P, the N, K, and Ca concentrations in leaves of plants receiving fertilization of any kind were similar or lower than those of control plants. In the case of $\mathrm{P}$, enhanced leaf content was apparent in plants receiving ChF-fa compared to the remaining treatments, including control (Table 1).

Table 1. Effect of fertilization through different (root/foliar) application methods on leaf essential macronutrient content of Origanum microphyllum. C: control (water); INM: integrated nutrient management (INM) by foliar application (INM-fa) or soil application (INM-sa); ChF: conventional fertilization by foliar application (ChF-fa) or soil application (ChF-sa); MPE-sa: mixture of plant extracts as biostimulant by soil application. Nutrient content was expressed per dry weight basis. Values represent the mean of three replicates \pm SEM.

\begin{tabular}{|c|c|c|c|c|c|}
\hline Treatment & $\mathbf{N}$ & $\mathbf{P}$ & $\mathbf{K}$ & $\mathrm{Ca}$ & Mg \\
\hline & \multicolumn{5}{|c|}{$\left(\mathrm{g} \mathrm{kg}^{-1}\right)$} \\
\hline C & $17.8 \pm 0.8^{a}$ & $2.4 \pm 0.1^{b}$ & $20.4 \pm 0.4^{\mathrm{a}}$ & $12.0 \pm 0.4^{\mathrm{a}}$ & $2.2 \pm 0.0^{\mathrm{a}}$ \\
\hline INM-fa & $12.5 \pm 0.6^{b c}$ & $2.7 \pm 0.0^{b}$ & $16.8 \pm 0.2^{b c}$ & $10.4 \pm 0.3^{\mathrm{ab}}$ & $2.1 \pm 0.1^{\mathrm{a}}$ \\
\hline ChF-fa & $11.1 \pm 0.7^{\mathrm{c}}$ & $3.3 \pm 0.0^{\mathrm{a}}$ & $18.7 \pm 0.5^{\mathrm{ab}}$ & $8.2 \pm 0.2^{b}$ & $2.3 \pm 0.0^{\mathrm{a}}$ \\
\hline INM-sa & $15.3 \pm 0.3^{\mathrm{ab}}$ & $2.6 \pm 0.1^{b}$ & $18.4 \pm 0.1^{\mathrm{ab}}$ & $9.9 \pm 0.3^{\mathrm{ab}}$ & $2.4 \pm 0.0^{\mathrm{a}}$ \\
\hline ChF-sa & $12.7 \pm 0.6^{b c}$ & $2.3 \pm 0.1^{b}$ & $15.2 \pm 0.1^{\mathrm{c}}$ & $8.5 \pm 0.3^{b}$ & $2.2 \pm 0.1^{\mathrm{a}}$ \\
\hline MPE-sa & $16.0 \pm 0.3^{\mathrm{ab}}$ & $2.5 \pm 0.0^{b}$ & $17.1 \pm 0.1^{b c}$ & $10.0 \pm 0.4^{\mathrm{ab}}$ & $2.3 \pm 0.0^{a}$ \\
\hline$p$ F-test & 0.029 & $<0.001$ & 0.003 & 0.052 & NS \# \\
\hline
\end{tabular}

Within each column different letters indicate significant differences. ${ }^{\#}$ NS: non-significant. 
Table 2. Effect of fertilization through different (root/foliar) application methods on leaf essential micronutrients content of Origanum microphyllum. C: control (water); INM: integrated nutrient management (INM) by foliar application (INM-fa) or soil application (INM-sa); ChF: conventional fertilization by foliar application (ChF-fa) or soil application (ChF-sa); MPE-sa: mixture of plant extracts as biostimulant by soil application. Nutrient content was expressed per dry weight basis. Values represent the mean of three replicates \pm SEM.

\begin{tabular}{cccccc}
\hline Treatment & Cu & Zn & Fe & Mn & B \\
\hline \multicolumn{7}{c}{$\left(\mathrm{mg} \mathrm{kg}^{-1}\right)$} \\
\hline C & $21.2 \pm 0.8^{\mathrm{abc}}$ & $32.9 \pm 0.8^{\mathrm{a}}$ & $640 \pm 38^{\mathrm{a}}$ & $39.6 \pm 1.5^{\mathrm{b}}$ & $59.9 \pm 1.3^{\mathrm{b}}$ \\
INM-fa & $15.9 \pm 0.4^{\mathrm{c}}$ & $27.7 \pm 0.6^{\mathrm{abc}}$ & $682 \pm 30^{\mathrm{a}}$ & $56.3 \pm 2.9^{\mathrm{a}}$ & $54.6 \pm 1.2^{\mathrm{b}}$ \\
ChF-fa & $25.8 \pm 0.9^{\mathrm{a}}$ & $30.8 \pm 0.6^{\mathrm{ab}}$ & $607 \pm 11^{\mathrm{ab}}$ & $56.8 \pm 2.9^{\mathrm{a}}$ & $60.3 \pm 1.3^{\mathrm{b}}$ \\
INM-sa & $16.7 \pm 0.4^{\mathrm{bc}}$ & $25.3 \pm 0.8^{\mathrm{c}}$ & $631 \pm 27^{\mathrm{a}}$ & $39.9 \pm 2.0^{\mathrm{b}}$ & $57.6 \pm 0.9^{\mathrm{b}}$ \\
ChF-sa & $16.2 \pm 0.6 \mathrm{~d}$ & $26.0 \pm 0.8^{\mathrm{bc}}$ & $406 \pm 23^{\mathrm{c}}$ & $35.5 \pm 1.0^{\mathrm{b}}$ & $58.2 \pm 1.1^{\mathrm{b}}$ \\
MPE-sa & $22.9 \pm 1.9^{\mathrm{ab}}$ & $29.9 \pm 0.9^{\mathrm{abc}}$ & $421 \pm 23^{\mathrm{bc}}$ & $37.4 \pm 1.5^{\mathrm{b}}$ & $70.6 \pm 1.1^{\mathrm{a}}$ \\
$p$ F-test & 0.033 & $0.045^{0}$ & 0.050 & $0.010^{3}$ & 0.044 \\
\hline
\end{tabular}

Within each column different letters indicate significant differences.

As far as the micronutrients are concerned, significant differences among all treatments were obtained for all elements. However, $\mathrm{Cu}, \mathrm{Zn}$, and Fe concentrations in leaves of plants receiving fertilization of any kind were similar or lower than those of control plants. Regarding the remaining elements, plants receiving foliar fertilization (i.e., INM-fa or ChF-fa) presented significantly higher leaf Mn content, while MPE-sa led to significantly higher leaf B content.

\section{Discussion}

This study represents the first step to bring in cultivation the Cretan marjoram O. microphyllum (Critically Endangered Cretan local endemic), evaluating the fertilization which is optimal for both plant growth and herbal quality. In this direction, the possibility of using organic fertilizer in place of conventional ones was pursued owing to both the lower environmental impact, and the possibility of future certification as 'organic' or 'environmentally friendly' product, either of which is valuable and well-appreciated in the value chains of herbal material markets [49-51]. Cretan marjoram is currently valued locally by people in western Crete for its strong sweet scent, calming and anti-spasmodic properties and therefore it is occasionally traded at local markets in dried form derived from wild-harvested mountainous populations [12]. O. microphyllum has a strong potential in the medicinal-cosmetic sector due to the fact that relevant phytochemical studies showed that its essential oil contains high levels of bioactive molecules such as terpinen4-ol, sabinene, and linalool, exhibiting antioxidant and antiproliferative activities against human cancer cell lines [52]. Furthermore, extracts from O. microphyllum aerial parts are effective against visceral leishmaniasis, a common disease in the world today [53]. Previous studies suggest the domestication of this neglected and underutilized plant as a promising case with agro-alimentary potential due to its domestic use in culinary preparations and for tea making [11]. In fact, these uses of O. microphyllum are in the same line with those of the globally well-appreciated sweet marjoram (Origanum majorana L.); the latter is considered nowadays as a traditional herbal medicine with approved indications by the European Medicines Agency [54]. This actually reflects health claims for O. majorana and safety of use based on traditional ethnobotanical knowledge for decades or centuries, and is associated with extant marketing and distribution channels in ornamental plants which can be profited for the trade of O. microphyllum as well at local and global scales [10].

Our study offered insight regarding the fertilization of O. microphyllum under pilot cultivation. In general, fertilization of $O$. microphyllum exerted limited effects on plant growth, and nutrient content, because soil was adequately rich in nutrients. However, it is worth noting that foliar application of both kinds of fertilizers enhanced Mn in leaves and biostimulant application to soil increased B. In general, the nutrients' concentrations in 
leaves of $O$. microphyllum ranged at levels almost similar to values reported in literature for sweet marjoram (O. majorana) of northern Greece [55] and Turkey [56], except for $\mathrm{Mg}, \mathrm{Zn}$, and B, with the latter being higher herein compared to both studies. As far as herbal material quality is concerned, it was indeed affected by fertilization. The quality criteria of the traded herbal material largely depend on the intended use, and they usually incorporate visual quality aspects [4,5]. For example, the intensity and uniformity of greenness of plant material is typically employed as a quality rating trait throughout the production and distribution chain [4]. At harvested full flowering stage, the leaf SPAD value of plants receiving foliar fertilization (i.e., INM-fa and ChF-fa) tended to be lower than the ones receiving root fertilization (i.e., INM-sa, ChF-sa, and MPE-sa); however, the SPAD values of all fertilization treatments were similar to control (Figure 2C). In line with these results, plants receiving both kinds of fertilization by foliar application were less green (i.e., higher $\mathrm{I}_{\mathrm{AD}}$ value) compared to plants receiving root fertilization (Supplementary Figure $\mathrm{S1C}$ ); however, again the $\mathrm{I}_{\mathrm{AD}}$ values of all fertilization treatments were similar to control. Accordingly, leaves of plants receiving ChF-sa and MPE-sa were darker (i.e., lower $\mathrm{L}^{*}$ value) than the ones of plants receiving foliar fertilization and those of control Figure S2C). In agreement with this trend, leaves of plants receiving foliar fertilization, but also INM-sa were yellower (i.e., lower $b^{*}$ value) compared to the rest of the treatments (Supplementary Figure S4C). When taken together, these results indicate that both kinds of fertilization applied by soil were associated with greener leaves in contrast to the foliar one. Other studies dealing with different species report that leaves were greener when plants received organic compared to conventional fertilizers [25].

An important quality aspect is the level of antioxidant compounds, including carotenoids, phenols, and flavonols [14]. In this line, previous studies suggest that organic fertilizers often promote higher content of antioxidant compounds [20,22-24]. In our study, O. microphyllum plants receiving root fertilization showed higher carotenoid content than the ones receiving foliar fertilization with INM-fa being less effective (Figure 4B). In all cases, fertilization stimulated total phenolic and flavonoid contents, with ChF-fa being less effective in the latter case (Figure 4C,D). Considering all three antioxidants' contents of O. microphyllum together, ChF-sa and INM-sa stand out as the most stimulatory fertilization schemes applied preferably through the root.

\section{Conclusions}

In this pilot field cultivation of Origanum microphyllum, the effect of fertilization on plant growth and herbal quality was evaluated for the first time in an attempt to develop knowledge on cultivation techniques regarding this promising new MAP crop.

In general, the fertilization schemes examined have exerted limited effects on O. microphyllum plant growth and nutrient content; the fertilization when applied through the root system was associated with enhanced visually perceived quality traits (increased green color intensity) and higher medicinal value (increased antioxidant compounds' content). The small size of leaves may have impeded the efficiency of the foliar application. Consequently, the results of this study suggest that the use of soil application upgraded visual quality and herbal antioxidant profile in O. microphyllum. Although the present field study is limited to a single cultivation cycle performed in a pilot way, it however presents first-time baseline values for a range of herbal quality features related to O. microphyllum, thus allowing for the consideration of an enhanced value chain for this neglected and underutilized species.

Supplementary Materials: The following are available online at https:/ / www.mdpi.com/article / 10.3390/agronomy12010094/s1, Figure S1: Effect of fertilization through different (root/foliar) application methods on leaf index of absorbance difference of Origanum microphyllum at: (A) vegetative; (B) early flowering; (C) full flowering stage, Figure S2: Effect of fertilization through different (root/foliar) application methods on leaf L value of Origanum microphyllum at: (A) vegetative; (B) early flowering; (C) full flowering stage, Figure S3: Effect of fertilization through different (root/ foliar) application methods on leaf a value of Origanum microphyllum at: (A) vegetation; (B) early flowering; 
(C) full flowering (C) stage, Figure S4: Effect of fertilization through different (root/foliar) application methods on leaf b value of Origanum microphyllum at: (A) vegetation; (B) early flowering; (C) full flowering (C) stage, Table S1: Product details of purchased fertilizers used in the pilot cultivation of Origanum microphyllum in Heraklion, Crete, Greece, Table S2: Experimental field soil properties of the research garden of the Hellenic Mediterranean University used for the fertilization trials on Origanum microphyllum.

Author Contributions: Conceptualization, G.T. (Georgios Tsoktouridis) and N.K.; methodology, K.P., D.F., G.T. (Georgios Tsaniklidis), V.A.T., F.B., E.S., M.J., E.L., I.I., G.T. (Georgios Tsoktouridis) and T.M.; software, K.P., D.F., G.T. (Giorgos Tsaniklidis), V.A.T., I.I. and T.M.; validation, D.F., V.A.T., F.B., E.S., M.J., E.L., I.I., T.M. and N.K.; formal analysis, K.P., D.F., G.T. (Georgios Tsaniklidis), V.A.T., F.B., E.S., I.I. and T.M.; investigation, K.P., D.F., G.T. (Georgios Tsoktouridis), V.A.T., F.B., E.S., M.J., E.L., I.I., G.T. (Georgios Tsaniklidis) and T.M.; resources, K.P., T.M., I.I., E.M. and G.T. (Georgios Tsoktouridis); data curation, K.P., D.F., G.T. (Georgios Tsaniklidis), V.A.T., F.B., E.S., M.J., E.L., I.I., G.T. (Georgios Tsoktouridis) and T.M.; writing—original draft preparation, K.P., D.F., G.T. (Georgios Tsoktouridis), V.A.T. and N.K.; writing—review and editing, K.P., D.F., G.T. (Georgios Tsoktouridis), V.A.T., F.B., E.S., M.J., E.L., I.I., G.T. (Georgios Tsaniklidis), E.M., T.M. and N.K.; visualization, V.A.T., D.F., F.B. and N.K.; supervision, T.M., D.F. and G.T. (Georgios Tsoktouridis); project administration, G.T. (Georgios Tsoktouridis); funding acquisition, K.P., N.K., T.M. and G.T. (Georgios Tsoktouridis). All authors have read and agreed to the published version of the manuscript.

Funding: This research has been co-financed by the European Union and Greek national funds through the Operational Program Competitiveness, Entrepreneurship and Innovation, under the call RESEARCH-CREATE-INNOVATE (project code: T1EDK-05380), entitled "Conservation and sustainable utilization of rare threatened endemic plants of Crete for the development of new products with innovative precision fertilization".

Data Availability Statement: All data supporting the results of this study are included in the manuscript and datasets are available upon request.

Acknowledgments: We are grateful to the laboratory staff and the undergraduate students Sofia Vouraki, Konstantinos Kalogiannakis, Faten Jamel Debouba, Mihail Kokotakis, Konstantinos Dermitzakis, Haralampos Liapakis, Emmanouella Vasilaki, Ioannis Papadakis, Emmanouil Haralampakis, and Georgios Stylianakis of the Hellenic Mediterranean University for their contributions, continued diligence, and dedication to their craft. The valuable comments of the editor and two anonymous reviewers are greatly acknowledged.

Conflicts of Interest: The authors declare no conflict of interest.

\section{References}

1. Bodeker, G.; Burford, G.; Volkov, A. Integrative, traditional and complementary medicine. In International Encyclopedia of Public Health, 2nd ed.; Quah, S.R., Ed.; Elsevier Academic Press: Amsterdam, The Netherlands, 2017; pp. $288-295$.

2. Jain, D.; Chaudhary, P.; Kotnala, A.; Hossain, R.; Bisht, K.; Hossain, M.N. Hepatoprotective activity of medicinal plants: A mini review. J. Med. Plants Stud. 2020, 8, 183-188. [CrossRef]

3. Hassanvand, F.; Rezaei Nejad, A.; Fanourakis, D. Morphological and physiological components mediating the silicon-induced enhancement of geranium essential oil yield under saline conditions. Ind. Crops Prod. 2019, 134, 19-25. [CrossRef]

4. Thamkaew, G.; Sjöholm, I.; Galindo, F.G. A review of drying methods for improving the quality of dried herbs. Crit. Rev. Food Sci. Nutr. 2021, 61, 1763-1786. [CrossRef]

5. Taheri-Garavand, A.; Mumivand, H.; Fanourakis, D.; Fatahi, S.; Taghipour, S. An artificial neural network approach for noninvasive estimation of essential oil content and composition through considering drying processing factors: A case study in Mentha aquatica. Ind. Crops Prod. 2021, 171, 113985. [CrossRef]

6. Cheminal, A.; Kokkoris, I.P.; Strid, A.; Dimopoulos, P. Medicinal and aromatic Lamiaceae plants in Greece: Linking diversity and distribution patterns with ecosystem services. Forests 2020, 11, 661. [CrossRef]

7. Grigoriadou, K.; Krigas, N.; Lazari, D.; Maloupa, E. Chapter 4-Sustainable use of mediterranean medicinal-aromatic plants. In Feed Additives: Aromatic Plants and Herds in Animal Nutrition and Health; Florou-Paneri, P.E., Christaki, E., Giannenas, I., Eds.; Elsevier Academic Press: London, UK, 2020; pp. 57-74.

8. Maloupa, E.; Krigas, N.; Grigoriadou, K.; Lazari, D.; Tsoktouridis, G. Conservation strategies for native plant species and their sustainable exploitation: Case of the Balkan Botanic Garden of Kroussia, N. Greece. In Floriculture Ornamental Plant Biotechnology: Advances and Topical Issues; Teixeira da Silva, J.A., Ed.; Global Science Books: Isleworth, UK, 2008; Volume 5, pp. 37-56.

9. Padulosi, S.; Mal, B.; Bala Ravi, S.; Gowda, J.; Gowda, K.T.K.; Shanthakumar, G.; Yenagi, N.; Dutta, M. Food security and climate change: Role of plant genetic resources of minor millets. Indian J. Plant Genet. Resour. 2009, 22, 1-16. 
10. Krigas, N.; Tsoktouridis, G.; Anestis, I.; Khabbach, A.; Libiad, M.; Megdiche-Ksouri, W.; Ghrabi-Gammar, Z.; Lamchouri, F.; Tsiripidis, I.; Tsiafouli, M.A.; et al. Exploring the potential of neglected local endemic plants of three Mediterranean regions in the ornamental sector: Value chain feasibility and readiness timescale for their sustainable exploitation. Sustainability 2021, $13,2539$. [CrossRef]

11. Libiad, M.; Khabbach, A.; El Haissoufi, M.; Anestis, I.; Lamchouri, F.; Bourgou, S.; Megdiche-Ksouri, W.; Ghrabi-Gammar, Z.; Greveniotis, V.; Tsiripidis, I.; et al. Agro-alimentary potential of the neglected and underutilized local endemic plants of Crete (Greece), Rif-Mediterranean coast of Morocco and Tunisia: Perspectives and challenges. Plants 2021, 10, 1770. [CrossRef]

12. Bourgou, S.; Ben haj Jilani, I.; Karous, O.; Megdiche-Ksouri, W.; Ghrabi-Gammar, Z.; Libiad, M.; Khabbach, A.; El Haissoufi, M.; Lamchouri, F.; Greveniotis, V.; et al. Medicinal-cosmetic potential of the local endemic plants of Crete (Greece), Rif-Mediterranean Coast of Morocco and Tunisia: Priorities for conservation and sustainable exploitation of neglected and underutilised phytogenetic resources. Biology 2021, 10, 1344. [CrossRef]

13. Malik, A.A.; Suryapani, S.; Ahmad, J. Chemical vs organic cultivation of medicinal and aromatic plants: The choice is clear. Int. J. Med. Arom. Plants 2011, 1, 5-13.

14. Ibrahim, M.; Jaafar, H.; Karimi, E.; Ghasemzadeh, A. Impact of organic and inorganic fertilizers application on the phytochemical and antioxidant activity of Kacip Fatimah (Labisia pumila Benth). Molecules 2013, 18, 10973-10988. [CrossRef]

15. Kakar, K.; Xuan, T.D.; Noori, Z.; Aryan, S.; Gulab, G. Effects of organic and inorganic fertilizer application on growth, yield, and grain quality of rice. Agriculture 2020, 10, 544. [CrossRef]

16. Rehim, A.; Amjad Bashir, M.; Raza, Q.-U.-A.; Gallagher, K.; Berlyn, G.P. Yield enhancement of biostimulants, Vitamin B12, and CoQ10 compared to inorganic fertilizer in radish. Agronomy 2021, 11, 697. [CrossRef]

17. Selim, M.M. Introduction to the integrated nutrient management strategies and their contribution to yield and soil properties. Int. J. Agron. 2020, 2821678. [CrossRef]

18. Gezahegn, A.M. Role of integrated nutrient management for sustainable maize production. Int. J. Agron. 2021, 9982884. [CrossRef]

19. Chen, Y.; Fanourakis, D.; Tsaniklidis, G.; Aliniaeifard, S.; Yang, Q.; Li, T. Low UVA intensity during cultivation improves the lettuce shelf-life, an effect that is not sustained at higher intensity. Postharvest Biol. Technol. 2021, 172, 111376. [CrossRef]

20. Asami, D.K.; Hong, Y.-J.; Barrett, D.M.; Mitchell, A.E. Comparison of the total phenolic and ascorbic acid content of freeze-dried and air-dried marionberry, strawberry, and corn using conventional, organic, and sustainable agricultural practices. J. Agric. Food Chem. 2003, 51, 1237-1241. [CrossRef]

21. Zhang, Y.; Ntagkas, N.; Fanourakis, D.; Tsaniklidis, G.; Zhang, Y.; Zou, J.; Cheng, R.; Yang, Q.; Li, T. The role of light intensity in mediating ascorbate content during postharvest tomato ripening: A transcriptomic analysis. Postharvest Biol. Technol. 2021, 180, 111622. [CrossRef]

22. Kazimierczak, R.; Hallmann, E.; Rusaczonek, A.; Rembiałkowska, E. Anioxidant content in black currants from organic and conventional cultivation. Food Sci. Technol. Res. 2008, 2, 57-61.

23. Wang, S.Y.; Chen, C.T.; Sciarappa, W.; Wang, C.Y.; Camp, M.J. Fruit quality, antioxidant capacity, and flavonoid content of organically and conventionally grown blueberries. J. Agric. Food Chem. 2008, 56, 5788-5794. [CrossRef]

24. Tõnutare, T.; Moor, U.; Mölder, K.; Põldma, P. Fruit composition of organically and conventionally cultivated strawberry 'Polka'. Agron. Res. 2009, 7, 755-760.

25. Amujoyegbe, B.J.; Opabode, J.T.; Olayinka, A. Effect of organic and inorganic fertilizer on yield and chlorophyll content of maize (Zea mays L.) and sorghum Sorghum bicolour (L.) Moench. Afr. J. Biotechnol. 2007, 6, 1869-1873. [CrossRef]

26. Strid, A. Atlas of the Aegean Flora; Part 1: Text \& Plates. Part 2: Maps; Botanic Garden and Botanical Museum Berlin: Berlin, Germany; Freie Universität Berlin: Berlin, Germany, 2016; Englera 33 (1 \& 2); ISBN 978-3-921800-97-3 (part 1); 978-3-921800-98-0 (part 2).

27. Kougioumoutzis, K.; Kokkoris, I.P.; Panitsa, M.; Strid, A.; Dimopoulos, P. Extinction risk assessment of the Greek endemic flora. Biology 2021, 10, 195. [CrossRef]

28. Bouyoucos, G.J. Hydrometer method improved for making particle size analysis of soils. Agron. J. 1962, 54, 464-465. [CrossRef]

29. Walkley, A.; Black, I.A. An examination of the Degtjareff method for determining soil organic matter, and a proposed modification of the chromic acid titration method. Soil Sci. 1934, 37, 29-38. [CrossRef]

30. Bremner, J.M. Nitrogen-total. In Methods of Soil Analysis, Part 3: Chemical Methods; SSSA Book Series 5; Sparks, D.L., Ed.; Soil Science Society of America, American Society of Agronomy: Madison, WI, USA, 1996; pp. 1085-1121.

31. Rhoades, J.D. Salinity: Electrical conductivity and total dissolved solids. In Methods of Soil Analysis, Part 3: Chemical Methods, SSSA Book Series 5; Sparks, D.L., Ed.; Soil Science Society of America, American Society of Agronomy: Madison, WI, USA, 1996; pp. 417-435.

32. Kuo, S. Phosphorus. In Methods of Soil Analysis, Part 3: Chemical Methods; SSSA Book Series 5; Sparks, D.L., Ed.; Soil Science Society of America, American Society of Agronomy: Madison, WI, USA, 1996; pp. 869-919.

33. Mulvaney, R.L. Nitrogen-Inorganic Forms. In Methods of Soil Analysis, Part 3: Chemical Methods; SSSA Book Series 5; Sparks, D.L., Ed.; Soil Science Society of America, American Society of Agronomy: Madison, WI, USA, 1996; pp. 1123-1184.

34. Thomas, G.W. Exchangeable Cations. In Agronomy Monographs; Page, A.L., Ed.; American Society of Agronomy, Soil Science Society of America: Madison, WI, USA, 2015; pp. 159-165.

35. Lindsay, W.L.; Norvell, W.A. Development of a DTPA soil test for zinc, iron, manganese, and copper. Soil Sci. Soc. Am. J. 1978, 42, 421-428. [CrossRef] 
36. Keren, R. Boron. In Methods of Soil Analysis, Part 3: Chemical Methods; SSSA Book Series 5; Sparks, D.L., Ed.; Soil Science Society of America, American Society of Agronomy: Madison, WI, USA, 1996; pp. 603-626.

37. Asayesh, E.J.; Aliniaeifard, S.; Askari, N.; Roozban, M.; Sobhani, M.; Tsaniklidis, G.; Woltering, E.J.; Fanourakis, D. Supplementary light with increased blue fraction accelerates emergence and improves development of the inflorescence in Aechmea, Guzmania and Vriesea. Agronomy 2021, 7, 485. [CrossRef]

38. Sørensen, H.K.; Fanourakis, D.; Tsaniklidis, G.; Bouranis, D.; Nejad, A.R.; Ottosen, C.-O. Using artificial lighting based on electricity price without a negative impact on growth, visual quality or stomatal closing response in Passiflora. Sci. Hortic. 2020, 267, 109354. [CrossRef]

39. Yang, L.; Fanourakis, D.; Tsaniklidis, G.; Li, K.; Yang, Q.; Li, T. Contrary to red, blue monochromatic light improves the bioactive compound content in broccoli sprouts. Agronomy 2021, 11, 2139. [CrossRef]

40. Ahmadi-Majd, M.; Mousavi-Fard, S.; Rezaei-Nejad, A.; Fanourakis, D. Carbon nanotubes in the holding solution stimulate flower opening and prolong vase life in carnation. Chem. Biol. Technol. Agric. 2022, in press. [CrossRef]

41. Ahmadi-Majd, M.; Rezaei Nejad, A.; Mousavi-Fard, S.; Fanourakis, D. Postharvest application of single, multi-walled carbon nanotubes and graphene oxide stimulates rose keeping quality. J. Hortic. Sci. Biotechnol. 2021, 11, 11374. [CrossRef]

42. Lichtenthaler, H.K.; Wellburn, A.R. Determinations of total carotenoids and chlorophylls a and b of leaf extracts in different solvents. Biochem. Soc. Trans. 1983, 11, 591-592. [CrossRef]

43. DuBois, M.; Gilles, K.A.; Hamilton, J.K.; Rebers, P.A.; Smith, F. Colorimetric method for determination of sugars and related substances. Anal. Chem. 1956, 28, 350-356. [CrossRef]

44. Mills, A.H.; Benton, A.J.; Jones, J.B., Jr. Plant. Analysis Handbook II: A Practical Sampling, Preparation, Analysis and Interpretation Guide; MicroMacro Publising, Inc.: Athens, GA, USA, 1996.

45. Dahnke, W.; Johnson, G.V. Testing soils for available nitrogen. In Testing Soils for Available Nitrogen; Westerman, R.L., Ed.; Soil Science Society of America: Madison, WI, USA, 1990; pp. 128-139.

46. Thomas, G.W.; Peaslee, D.E. Testing soils for phosphorus. In Soil Testing and Plant Analysis; Walsh, L.M., Beaton, J.D., Eds.; Soil Science Society of America: Madison, WI, USA, 1973; pp. 115-132.

47. Doll, E.C.; Lucas, R.E. Testing soils for potassium, calcium, and magnesium. In Soil Testing and Plant Analysis; Walsh, L.M., Beaton, J.D., Eds.; Soil Science Society of America: Madison, WI, USA, 1973; pp. 133-151.

48. Sims, J.T.; Johnson, G.V. Micronutrient soil tests. In Micronutrients in Agriculture, 2nd ed.; Mortvedt, J.J., Ed.; Soil Science Society of America: Madison, WI, USA, 1991; pp. 427-476.

49. Hamilton, A.C. Medicinal plants, conservation and livelihoods. Biodivers. Conserv. 2004, 13, 1477-1517. [CrossRef]

50. Paschalidis, K.; Fanourakis, D.; Tsaniklidis, G.; Tzanakakis, V.A.; Bilias, F.; Samara, E.; Kalogiannakis, K.; Debouba, F.J.; Ipsilantis, I.; Tsoktouridis, G.; et al. Pilot cultivation of the vulnerable Cretan endemic Verbascum arcturus L. (Scrophulariaceae): Effect of fertilization on growth and quality features. Sustainability 2021, 13, 14030. [CrossRef]

51. Laird, S.A.; Pierce, A.R. Promoting Sustainable and Ethical Botanicals: Strategies to Improve Commercial Raw Material Sourcing: Results from the Sustainable Botanicals Pilot Project Industry Surveys, Case Studies and Standards Collection; Rainforest Alliance: New York, NY, USA, 2002.

52. Marrelli, M.; Conforti, F.; Formisano, C.; Rigano, D.; Apostolides Arnold, N.; Menichini, F.; Senatore, F. Composition, antibacterial, antioxidant and antiproliferative activities of essential oils from three Origanum species growing wild in Lebanon and Greece. Nat. Prod. Res. 2016, 30, 735-739. [CrossRef]

53. Gotsiou, P.; Naxakis, G.; Skoula, M. Diversity in the composition of monoterpenoids of Origanum microphyllum (Labiatae). Biochem. Sytem. Ecol. 2002, 30, 865-879. [CrossRef]

54. European Medicines Agency. Available online: https://www.ema.europa.eu/en (accessed on 3 December 2021).

55. Karagiannidis, N.; Panou-Filotheou, H.; Lazari, D.; Ipsilantis, I.; Karagiannidou, C. Essential oil content and composition, nutrient and mycorrhizal status of some aromatic and medicinal plants of northern Greece. Nat. Prod. Commun. 2010, 5, 823-830. [CrossRef]

56. Zengin, M.; Ozcan, M.M.; Cetin, U.; Gezgin, S. Mineral contents of some aromatic plants, their growth soils and infusions. J. Sci. Food Agric. 2008, 88, 581-589. [CrossRef] 